\title{
Ocurrencia de Cucumber mosaic virus en Antirrhinum majus en Argentina
}

\author{
Joel D. Arneodo*, Fabiana A. Guzmán, Claudia F. Nome \& Luis R. Conci \\ IFFIVE - INTA, Camino 60 Cuadras km 51/2, X5020ICA Córdoba, Argentina, e-mails: arneodoj@correo.inta.gov.ar, \\ lconci@correo.inta.gov.ar
}

(Aceptado para publicación el 17/11/2004)

Autores para correspondencia: Joel D. Arneodo y Luis R. Conci

\begin{abstract}
Occurrence of Cucumber mosaic virus on Antirrhinum majus in Argentina

Cucumber mosaic virus (CMV), subgroup I, was detected infecting snapdragon (Antirrhinum majus) in plant nurseries in the province of Córdoba (Argentina). The virus was identified by serology, electron microscopy, and host range studies. This is the first report of CMV in snapdragon in Argentina.
\end{abstract}

El "conejito" (Antirrhinum majus L.) es una especie ornamental muy difundida en Argentina. Es susceptible, entre otros fitovirus, al Cucumber mosaic virus (CMV) (Brunt et al., University Press, Cambridge. 1996), género Cucumovirus, familia Bromoviridae. En Argentina, el CMV ha sido detectado en numerosas especies hortícolas y malezas (Gracia, O., RIA - INTA, 17:33. 1982).

Durante el año 2003, en viveros de la provincia de Córdoba (Argentina), se observaron plantas de "conejito" de porte achaparrado, con área foliar reducida, leve mosaico y menor número o ausencia de flores (Figura 1A). El análisis al microscopio electrónico ("leaf dip") de las mismas reveló la presencia de partículas isométricas, semejantes a virus, de unos $30 \mathrm{~nm}$ de diámetro (Figura 1B). El patógeno fue transmitido mecánicamente, a partir de una planta de "conejito", a Nicotiana benthamiana Domin., N. glutinosa L., N. rustica L., N. occidentalis Wheeler, Chenopodium amaranticolor Coste \& Reyn., Gomphrena globosa L. y Physalis sp. La severa sintomatología ocasionada consistió en ampollamiento, distorsión de la lámina foliar y mosaico en las especies de Nicotiana (Figura 1C), seguido de necrosis en $N$. bentamiana y $N$. occidentalis. G. globosa y Physalis mostraron mosaico y leve deformación de hojas. $C$. amaranticolor expresó lesiones cloróticas locales (Fig. 1D). El análisis de la planta fuente de inóculo e indicadoras por ELISA indirecto con antisuero anti-CMV (Dr. K. Shohara, Japón), permitió identificar al patógeno como CMV. Mediante DAS-ELISA con antisueros específicos para los subgrupos I y II del CMV (Agdia), se determinó que el aislamiento estudiado, así como los correspondientes a otras siete plantas de "conejito" adquiridas en el comercio, con

\footnotetext{
* Becario de CONICET
}

diverso grado de severidad en los síntomas, pertenece al subgrupo I. Este es el primer registro de CMV en $A$. majus en Argentina.

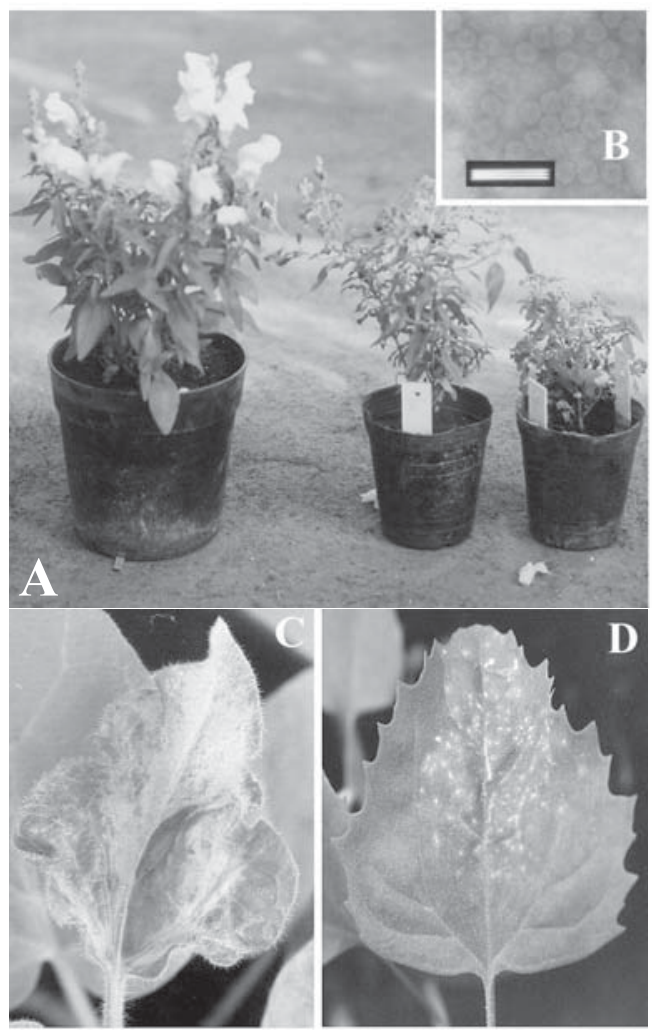

FIG. 1 - (A) Planta sana (izq.) y enfermas (der.) de A. majus. (B) Partículas de CMV observadas al microscopio electrónico (Barra: $100 \mathrm{~nm}$ ). (C) Síntomas de mosaico y ampollamiento y (D) lesiones cloróticas locales, ocasionados por el CMV en N. glutinosa y Ch. amaranticolor respectivamente. 